\title{
CTSD Gene
}

National Cancer Institute

\section{Source}

National Cancer Institute. CTSD Gene. NCI Thesaurus. Code C28406.

This gene plays a role in apoptosis and epidermal differentiation. 